\title{
ZAŠTITNE OZNAKE OTOČNIH PROIZVODA U KONTEKSTU HRVATSKOG I EU-ZAKONODAVSTVA
}

\author{
UDK: 36664 (497.5) (210.7) \\ Primljeno: 10. V. 2018. \\ Stručni rad
}

\begin{abstract}
Autohtoni proizvodi, karakteristični za otočni prostor, specifični su segment otočnog gospodarstva, a hrvatski im zakonodavac omogućuje promociju i zaštitu na tržištu oznakama zemljopisnog podrijetla, oznakama izvornosti, zajamčenošću tradicionalnih specijaliteta, oznakama 'hrvatski eko-proizvod' i 'hrvatski otočni proizvod'. Europska unija poziva se na odredbe članka 174. Lisabonskog ugovora ističući potrebu razvijanja politike gospodarske, socijalne i teritorijalne kohezije za otočna područja, kao priliku za smanjivanje razvojne nejednakosti s kopnenim regijama. Za definiranje pojma,,otok“ i uopće otočne problematike značajan je amandman na Rezoluciju Parlamenta o posebnoj situaciji otoka kojim se konstatira da otoci nisu dobili financijsku pomoć za razdoblje od 2014. do 2020., te da članak 174. Lisabonskog ugovora nije jasan.

U radu se kao daljnji EU-instrument otočne politike ističe Izvješće Komisije o opravdanosti uvođenja neobavezne oznake kvalitete ,proizvod otočne poljoprivrede“ jer iskazuje neslaganje s tom idejom prema Uredbi (EU) o sustavima kvalitete za poljoprivredne i prehrambene proizvode br. 1151/2012. Bitni su i Zaključci Vijeća jer se smatra da svaka otočna članica može izraditi svoj program o rješavanju problema otočnih poljoprivrednika. Kao EU-akti političke naravi, nemaju obvezujuću snagu, ali potrebno ih je pratiti imajući u vidu interese proizvođača na hrvatskim otocima koji su uključeni u nacionalni sustav kvalitete „Hrvatski otočni proizvod“. Uvođenjem spomenute neobavezne EU-oznake za poljoprivredne proizvode s hrvatskih otoka, proizvođači bi imali štetu s pozicije slobodnog tržišnog natjecanja jer bi se uvrstili uz svoje konkurente. Na kraju se spominju EU-akcije koje se poduzimaju na otocima u odnosu na transnacionalne mreže, a odraz već imaju na hrvatskim naseljenim otocima.
\end{abstract}

Ključne riječi: otočni proizvod, oznaka kvalitete, proizvod otočne poljoprivrede, akti EUpolitike, hrvatski otočni proizvod

\section{UVODNO}

Nakon usvajanja Lisabonskog ugovora 2009. godine, Unija razvija politiku gospodarske, socijalne i teritorijalne kohezije, nastojanjem da se smanje razvojne nejednakosti regija, što se odnosi i na razlike između otoka i kopnenih regija. Preusmjeravanjem financijskih sredstava EU-fondova u vrijeme krize „u područja u

1 Mr. sc. Majda Rubić, , Hermanova 16D, 10020 Zagreb, viša stručna savjetnica u Ministarstvu regionalnog razvoja i fondova EU-a. Mišljenja autorice iznesena u ovome radu ne predstavljaju nužno i stajališta Ministarstva regionalnog razvoja i fondova Unije. 
kojima će utjecaj na gospodarsku aktivnost i zapošljavanje biti izravan i trenutačan“,, putem akata soft lawa radi se na ublažavanju posljedica financijske i gospodarske krize u Uniji. U poljoprivredi, ribarstvu, maslinarstvu, vinogradarstvu i stočarstvu, na otocima se proizvode autohtoni proizvodi koji imaju dodatan značaj i sastavni su dio otočne tradicije. Riblji otočni proizvodi i tradicionalno ribarstvo s nastojanjem da se osigura kontinuitet određenih oblika tradicionalnih djelatnosti na moru i s njima povezanih običaja i vjerovanja, postali su i formalnopravno dijelom otočnog kulturnog identiteta.

Za hrvatske otoke vrijedan je primjer dobre prakse inicijativa znanstvene zajednice u okvirima podijeljene nadležnosti članica i Europske unije na području ribarstva. ${ }^{3}$ Očuvanje se ostvaruje propisima za zaštitu kulturnih dobara i drugim propisima s područja pružanja usluga u turizmu, te propisima o ribarstvu. Postupkom registracije tradicijskih ribolovnih vještina na lokalnoj i nacionalnoj razini željela se osigurati kulturna raznolikost, a priznanjem svojstva jedinstvenog blaga provoditi mjeru zaštite kako bi se izbjeglo nestanak, uništenje ili pretjeranu komercijalizaciju tog kulturnog dobra. ${ }^{4}$

Imajući u vidu navedeni postupak i zaštitu tradicijskih ribolovnih vještina, Ministarstvo turizma unijelo je ribolovni turizam u svoj Zakon o pružanju usluga u turizmu kao oblik turističke ponude. ${ }^{5}$ Tradicijske ribolovne vještine kao novi oblik turističke usluge provodit će se nakon usklađenja s propisima o ribarstvu Ministarstva poljoprivrede.

U mnogim se studijama o novoj situaciji europskih otoka govori kao o otocima s potencijalima i novim mogućnostima što će se stvoriti uz pomoć investicija. ${ }^{6}$ Referiraju se na odredbe članka 174. stavak 1. UFEU/L-a: „,Radi promicanja svog sveukupnog skladnog razvitka, Unija razvija i provodi svoja djelovanja koja dovode do ojačavanja gospodarske, socijalne i teritorijalne kohezije“. Funkcioniranje kohezijske politike reformirano je i s idejom primjene načela partnerstva putem razvijanja transeuropskih mreža na području prijevoza, telekomunikacija i energetike. ${ }^{7}$ Odbor regija EU-a poziva članice da u svoje operativne programe uključe postojeće i potencijalne grupacije (EGTS-ove), kao alate za bolje ostvarenje potreba na lokalnoj razini u prekograničnim područjima, ali imajući u vidu nužnost da sve države članice sudionice mogu provjeriti je li takvo pristupanje u skladu s njihovim javnim interesom ili javnom politikom.

2 O novoj kohezijskoj politici u: Komunikacija Komisije Parlamentu, Vijeću, Gospodarskom i socijalnom odboru i Odboru regija, dokument 52014DC0473 iz 2014. g.

3 Članak 2. i 4. UFEU/L-a.

4 Rješenje o utvrđivanju Tradicijske ribolovne vještine, običaji i vjerovanja na Jadranu kao nematerijalnog kulturnog dobra Ministarstva kulture, objavljeno je u Narodnim novinama br. 44/2017.

5 U članku 83. Zakona o pružanju usluga u turizmu koji je u primjeni od 1. siječnja 2018., kao turistička usluga u posebnom obliku turističke ponude navodi se i ribolovni turizam, a uvjeti za pružanje te usluge su u članku 94. Zakona (NN, br. 130/2017).

6 Tako u studiji ,Islands of the EU: Taking account of their specific needs in EU policy“.

7 Unutar čl. 170. st. 1. UFEU/L-a o ostvarivanju mjera iz čl. 174. UFEU/L-a. 
U pravilu, iako o prostornom uređenju članica nema obvezujuće EU-pravne stečevine, akti o politikama Unije prate se jer donose mjere o novoj kohezijskoj politici (soft law: rezolucija, deklaracija, mišljenje, komunikacija, izvješće, zaključci, studije, akcijski planovi i slično). Rezolucija o posebnoj situaciji otoka kao politički akt Europskog parlamenta vrijedi za sve europske otoke i otočne članice što se mora imati u vidu prilikom donošenja nacionalnih zakona u području otočne politike. Za razliku od neobvezujućih akata soft lawa, EU-uredbe obvezujuće su u cijelosti i direktno se primjenjuju u državama članicama. Unija već neko vrijeme radi na pristupu pojednostavljivanja regulatornog okruženja zajedničke poljoprivredne politike, a rezultat je Uredba (EU) Europskog parlamenta i Vijeća br. 1151/2012 o sustavima kvalitete za poljoprivredne i prehrambene proizvode (dalje u tekstu: Uredba br. 1151/2012), kojom se predviđa uvođenje zajedničke oznake za otočne poljoprivredne proizvode koji su dio strateškog okvira za sve otoke. Intencija je na području zajedničke poljoprivredne politike Unije ustrajanje u pojednostavljenju propisa o kvaliteti prehrambenih proizvoda koji potječu s otoka. Kako bi se smanjile razvojne nejednakosti između otoka i kopnenih regija, uvodi se novi izraz ili oznaka „proizvod otočne poljoprivrede“ u Uredbi br. 1151/2012. Donesena je u svrhu održavanja raznolikosti poljoprivredne proizvodnje u Uniji, pa se pridaje važnost gastronomskoj baštini i politici predstavljanja kvalitete poljoprivrednih proizvoda s ciljem informiranja kupaca i potrošača o značajkama spomenutih proizvoda pod uvjetima pravednog tržišnog natjecanja.

Nastoji se utjecati na ruralno gospodarstvo i moguénost zapošljavanja kako bi se ostvarilo uvjete za socijalnu i teritorijalnu koheziju. Glede sustava označivanja poljoprivrednih i prehrambenih proizvoda intencija je da se podliježe općim pravilima o usklađivanju zakonodavstva država članica o označivanju, prezentiranju i reklamiranju prehrambenih proizvoda, kako se ne bi stvaralo zabunu ili zabludu kod potrošača. Ujedno, podupire se proizvodnju raznovrsne kvalitete proizvoda $\mathrm{s}$ različitim oznakama uz ostvareni potencijal jer bi to moglo povoljno utjecati na ruralno gospodarstvo otoka. U ovome radu posebna je pažnja usmjerena na Izvješće Komisije i Zaključke Vijeća kojima se izražava neslaganje s načinom uvođenja dobrovoljne oznake „proizvod otočne poljoprivrede“ prema Uredbi br. 1151/2012, a pri tome imamo u vidu popis proizvoda hrvatskih otoka s oznakom „Hrvatski otočni proizvod“".

\section{EU-INSTRUMENTI OTOČNE POLITIKE}

Prijedlog Rezolucije Europskog parlamenta o posebnoj situaciji otoka od 27. siječnja 2016., imao je u vidu krizu koja je ozbiljno utjecala na potencijalni razvoj otočnih regija u nepovoljnom položaju u odnosu na kopnene regije, što ne vodi postizanju dugoročnog cilja na području gospodarske i socijalne kohezije Unije. Od Komisije se prema Rezoluciji očekuje pružiti jasnu definiciju vrsta poteškoća otočnih regija povezano s člankom 174. UFEU/L-a te sukladno s definicijom Eurostata uspostaviti homogenu skupinu svih otoka Unije, kao i izraditi Program za otoke i 
Bijelu knjigu za praćenje razvoja otoka. Ali Prijedlog Rezolucije nije usvojen, u ime Odbora za regionalni razvoj podnijela je amandman bugarska europarlamentarka Iskra Mihaylova koji je bitno utjecao na konačan tekst Rezolucije o posebnoj situaciji otoka (B8-0165/2016). Obveza razlikovanja između otoka općenito i otoka s glavnim gradom, zatim o važnosti pružanja potpore zbog depopulacije na otocima, više se ne traži da bude ovisna o definiciji Eurostata, izbrisana je iz točke 3. Rezolucije.

Amandman dalje ističe da otoci definirani kao regije razine NUTS-2 i NUTS-3 sa zajedničkim i trajnim posebnim obilježjima koja ih jasno razlikuju od kontinentalnih područja, uopće nisu primili namjenska sredstva u pripremi financijskog programskog razdoblja od 2014. do 2020. Stoga je revidiran tekst na način da je u točki 5. Rezolucije dodana konstatacija o potrebi postojanja prave definicije ili kategorizacije kojom bi se uzele u obzir razlike i posebnosti te posebna situacija otoka. U novoj točki 6 . podsjeća se i traži da se zadrže odobreni posebni porezni dogovori kao kompenzacija za prirodne nedostatke i trajne demografske poteškoće, imajući u vidu što su samo određene vrste otoka razine NUTS-2 i NUTS3 primili samo mogućnost prilagodbe stopa financiranja. ${ }^{8} \mathrm{U}$ točki 7 . Rezolucije istaknuta je potreba bolje povezanosti pomorskim rutama radi uravnoteženog teritorijalnog razvoja otoka. U točki 11. dodana je važnost niskog poreza i politika smanjenja birokracije kao ključnih poticaja za prihvaćanje ulaganja. Prema Rezoluciji Komisija treba dati jasnu definiciju vrste trajnih geografskih, prirodnih i demografskih poteškoća s kojima se otočne regije suočavaju i objasniti primjenu formulacije iz čl. 174. UFEU/L-a, ali kriterije će dostaviti otočne članice, jer je potrebna definicija ili kategorizacija otoka s njihovim razlikama i posebnostima, te situacijom u kojoj se nalaze. Ukoliko definicija izostane, Komisija je ovlaštena definirati posebnu situaciju otoka na temelju članka 174. UFEU/L-a i uspostaviti homogenu skupinu koju čine sva otočna područja. ${ }^{9}$

8 Članak 121. EFRR Uredbe br. 1303/2013: Stopu sufinanciranja prioriteta iz fondova može se prilagoditi uzimajući u obzir: (4) obuhvaćenost područja koja su značajno i trajno, demografski i prirodno ograničena, te definirana kako slijedi: a) otočne države članice koje su prihvatljive za Kohezijski fond i drugi otoci osim onih na kojima je smješten glavni grad države članice ili koji imaju čvrstu vezu $\mathrm{s}$ kopnom; b) planinska područja koja kao takva utvrđuje nacionalno zakonodavstvo države članice; c) rijetko (tj. s manje od 50 stanovnika po kvadratnom km) naseljena područja; d) uključivanje najudaljenijih regija, kako je navedeno u čl. 349. UFEU/L.

9 Parlamentarna pitanja od 26. siječnja 2016. upućena Komisiji za usmeni odgovor o otocima (O-000013/2016 - B8-0106/2016 u skladu s člankom 128. Poslovnika: Može li Komisija pružiti jasnu definiciju vrste trajnih prirodnih ili demografskih poteškoća iz čl. 174. UFEU/L-a kojima će, prema očekivanjima, otoci koji se odnose na razine NUTS-2 i NUTS-3 biti izloženi?; Koji su specifični instrumenti i resursi kohezijske politike dostupni za rješavanje poteškoća koje proizlaze iz otočnog položaja?; Kako će Komisija u budućnosti rješavati pitanje usklađenosti s člankom 174. UFEU/L-a kada je riječ o priznavanju trajnih poteškoća kojima su izloženi otoci koji se odnose na razine NUTS-2 i NUTS3 kao trajna prepreka koja može utjecati na ostvarivanje ciljeva kohezijske politike?; Dijeli li Komisija mišljenje da bi osim BDP-a trebalo razmotriti i druge pokazatelje koji nadilaze mjerenje gospodarske proizvodnje i kojima se uzimaju u obzir posebnosti otoka, kao što je regionalni indeks konkurentnosti, u cilju boljeg odražavanja ekonomske i društvene osjetljivosti koja proizlazi iz trajnih prirodnih poteškoća kojima su izložene takve regije. 


\section{2.a. ZAŠTITNE OZNAKE ZA POLJOPRIVREDNE PROIZVODE}

Sustavom oznaka zaštite u Europskoj uniji pomaže se održanje izvornih proizvoda, smatraju se dijelom kulturnog naslijeđa Unije, a pružaju se iste mogućnosti svim proizvođačima izbjegavajući monopol na tržištu i zaštitom proizvoda s različitim oznakama. Hrvatskim Zakonom o oznakama zemljopisnog podrijetla i oznakama izvornosti proizvoda i usluga, ${ }^{10}$ definirane su oznake odgovarajuće onima u Uredbi (EU) br. 510/2006 o zaštitnoj oznaci zemljopisnog podrijetla (oznaka: „ZOZP“) i zaštiti oznake izvornosti (oznaka: ,ZOI“) poljoprivrednih i prehrambenih proizvoda, te i Uredbi (EU) br. 509/2006 o poljoprivrednim i prehrambenim proizvodima kao zajamčeno tradicionalnim specijalitetima (oznaka: „ZTS“). Oznake proizvoda povezane su s određenim teritorijem (,ZOZP“), jamče kvalitetu (,ZOI“), ili način proizvodnje koji potječe iz određene države (,ZTS“).

Oznake izvornosti pružaju dokaz o dubljoj vezi s mikropodručjem podrijetla proizvoda i sve faze proizvodnje moraju biti s tog područja za razliku od oznake zemljopisnog podrijetla za koju je dovoljna jedna faza proizvodnje. Pravna zaštita oznaka ostvaruje se u upravnom postupku koji vodi Državni zavod za intelektualno vlasništvo, pravo korištenja oznaka traje deset godina od dana upisa ovlaštenog korisnika u registar i može se produžavati neograničeni broj puta.

Uredba br. 1151/2012 većim je dijelom zamijenila Uredbe br. 509/2006 i br. 510/2006 radi jasnoće i transparentnosti. Jedinstveni zakonodavni okvir od tada čine nove ili ažurirane odredbe Uredbi br. 509/2006 i br. 510/2006, kao i njihove odredbe koje se zadržavaju dok se u kasnijoj fazi u cijelosti ne primijeni jedinstveno zakonodavstvo. Jednoobraznim pristupom zaštite „ZOI“ i „ZOZP“ upisuju se u registar EU-a, donijet će se odredbe za razvoj tih oznaka na razini Unije. U državama članicama očekuje se prijelazna zaštita na nacionalnoj razini bez utjecaja na trgovinu Unije ili na međunarodnu trgovinu, tj. bez izvoza (točka 24. Uredbe br. 1151/2012). Budući da je područje primjene Uredbe br. 1151/2012 ograničeno, za otočne proizvođače važno je da se njena pravila ne odnose na ekološke proizvode ili one najudaljenijih otoka. U prijelaznim razdobljima (do 10 godina), mogu se koristiti već registrirani nazivi uz druge nazive samo ako se to posebno uredi propisom. Proizvodi s postojećim oznakama „ZOZP“ i „ZOI“ ostaju zaštićeni na temelju ove Uredbe i automatski se upisuju u registar, a za proizvode s oznakom „ZTS“ drži se kako nisu ostvarili potencijal: „,S obzirom da zainteresirane stranke nisu dovoljno dobro razumjele i da se uloga identifikacije tradicionalnih proizvoda može bolje ostvariti na razini države članice ili regije primjenjujući načelo supsidijarnosti, ovu mogućnost bi trebalo ukinuti. U pogledu iskustva, sustav se treba baviti pridržavanjem prava samo za nazive diljem Unije“ (točka 35. Uredbe br. 1151/2012). Proizvod oznake „ZTS“ treba biti registriran uz utvrđene kriterije, novim znakom.

Položaj proizvoda na tržištu EU-a nadzire se na način da postavljeni zahtjev za označavanje proizvoda ispituju nacionalna tijela države članice. Odbor za politiku

10 Zakon je objavljen u NN, br. 173/2003, 186/2003, 76/2007, 49/2011. 
kvalitete poljoprivrednih proizvoda pomaže Komisiji donijeti provedbene akte s pravilima o kontroli oznaka zemljopisnog podrijetla i zajamčeno tradicionalnim proizvodima, prema višegodišnjim nacionalnim planovima i izvješćima koje donose države članice.

Nacionalna tijela države članice dužna su ispitati ispunjavaju li oznake izvornosti ili zemljopisnog podrijetla i zajamčeno tradicionalnog specijaliteta uvjete iz Uredbe br. 1151/2012. Registrirana oznaka mogla bi se poništiti utvrdi li se da je u suprotnosti s prethodnom oznakom „ZOI“ ili „ZOZP“, međutim, to se ne odnosi na oznake „ZTS“ i za neobavezne oznake kvalitete. Komisija je nadležna za odlučivanje o registraciji zaštićenih oznaka, a prije izrade provedbenih akata obavlja stručna savjetovanja i komunikaciju s Parlamentom i Vijećem. Komisija može donijeti provedbene akte koji osiguravaju prijelazno razdoblje od pet godina za uporabu zaštićenih oznaka „ZOI“ i „ZOZP“. Općenito su oznake dobro prihvaćene jer njeguju veze s tradicijom, obnavlja se željeni način života u manjim zajednicama i podupire socijalna povezanost, njihovi proizvođači mogu ostvariti pravo na povećanu tržišnu cijenu i potrošačima pružiti obavijest o obilježjima dodane vrijednosti svojih proizvoda.

Projekti u agroturizmu pomogli su otoke dovesti do toga da postanu nova ekodestinacija za posjetitelje uz suradnju partnera na lokalnoj, županijskoj i državnoj razini. Ekoznak je četvrta vrsta označavanja poljoprivrednih proizvoda, a ova oznaka je dobrovoljna. Svrha je smanjivanje negativnog učinka proizvodnje i potrošnje na okoliš, zdravlje, klimu i prirodna dobra, namijenjena je prvenstveno potrošačima. Europska unija s najvećim udjelom u svjetskoj trgovini poljoprivredno-prehrambenim proizvodima ima najbolju reputaciju u svijetu kad je riječ o prehrambenim proizvodima visoke kvalitete. Novim programom promocije za promicanje svojih prehrambenih proizvoda nastoji zainteresirati potrošače o oznakama kvalitete zemljopisnog podrijetla i ekoloških proizvoda. ${ }^{11}$ Budući da sektorsko financiranje treba biti namijenjeno programima kojima se promiče održivi uzgoj koza i ovaca, to se primjer preventivnog cijepljenja i dvostrukog označavanja koza pokazuje od nemalog značaja za proizvođače s naših otoka.

Obiteljska poljoprivredna gospodarstva i mali poduzetnici s proizvodnjom kozjeg sira mogu dobiti Ekoznak Unije kada su svi sastojci proizvedeni u skladu $\mathrm{s}$ odredbama ekološke proizvodnje, temeljem zakonskih propisa o poljoprivredi. ${ }^{12}$ Kozji sir kao ekološki ili organski proizvod dobiva se bez upotrebe umjetnih gnojiva, kemikalija i pesticida, cijena može biti viša za 20 do $50 \%$ u odnosu na konvencionalne proizvode. ${ }^{13} \mathrm{Na}$ otocima je značajna i osjetljiva proizvodnja malih

11 Europska komisija izdala je priopćenje za tisak 12. siječnja 2018. „Promicanje europskih poljoprivrednih proizvoda: Komisija povećava iznos sredstava“. Radi se dodatnim sredstvima u iznosu od 169 milijuna eura, 27 milijuna eura više nego u okviru programa iz 2017. Prijedlozi se zaprimaju do 12. travnja 2018., a Komisija ocjenjuje prijedloge i na jesen 2018. će objaviti korisnike kojima se odobrava financiranje.

12 Ekocertifikat u Hrvatskoj dodjeljuje Ministarstvo zaštite okoliša i prirode.

13 Ekološku oznaku imaju kozji sirevi kao jamstvo potrošaču da može nabaviti prirodan i zdrav proizvod. OPG Bajević deveterostruki je šampion RH u klasi proizvoda s kozjim sirevima. 
poduzetnika, jer se većinski dio otočnog stanovništva bavi uzgojem koza i ovaca, otočna poljoprivredna proizvodnja ovisi o stočarskoj proizvodnji gdje je važan uzgoj koza i ovaca. Proizvodnja kozetine i ovčetine triput je veća na otocima od prosjeka u Uniji. Međutim, označavanjem koza u hrvatskom ekološkom uzgoju, čini se, dolazi do neželjene zablude proizvođača i potrošača o ekoznaku kvalitete kozjih proizvoda. ${ }^{14}$

\section{2.b. IZVJEŠĆE KOMISIJE I ZAKLJUČCI VIJEĆA O UREDBI BR. 1151/2012}

Komisija ima veliki utjecaj na sadržaj pojedinih pravnih akata, pa i u postupku njihova usvajanja kada se radi o EU otočnoj politici. Prema Uredbi br. 1151/2012, Komisija je ovlaštena donositi delegirane akte čime ostvaruje, iznimno, i zakonodavnu ulogu. Komisija je zadužena donijeti provedbene propise s kriterijima o korištenju dobrovoljne oznake kvalitete „proizvod otočne poljoprivrede“ koja ima europski značaj, također i o uvjetima uporabe takvog proizvoda. ${ }^{15} \mathrm{O}$ odredbama Uredbe br. 1151/2012 kojom su ovom oznakom obuhvaćeni otočni proizvodi namijenjeni ljudskoj prehrani prema Prilogu I. Ugovoru i čije sirovine dolaze s otoka ili za prerađevine kojih se prerada odvija na otoku, ako to značajno utječe na neka svojstva konačnog proizvoda, izjasnili su se Komisija, potom i Vijeće.

Komisija je na poziv Parlamenta i Vijeća podnijela Izvješće o svom neslaganju za uvođenjem neobavezne oznake ili izraza o kvaliteti ,proizvod otočne poljoprivrede“. U Izvješću se očitovala o svom istraživanju diljem Unije, o savjetovanjima s državama članicama i dionicima, te o Upitniku sa znanstveno-političkom analizom postojećih sustava označivanja (Upitnik je iz 2013. pa pretpostavljamo zbog vremenskog predznaka nije uključio hrvatski pravni sustav označivanja proizvoda, tzv. „HOP“). ${ }^{16}$ Izražavajući svoje neslaganje s uvođenjem oznake „proizvod otočne poljoprivrede“, Komisija ističe da ova EU-oznaka nema naziv određenog otoka niti logotip, već samo opis proizvoda u Prilogu I. čije sirovine dolaze s otoka, namijenjenima ljudskoj prehrani. Izvješćem Komisija problematizira i definiciju pojma „otok“ u kontekstu one definicije koja vrijedi za Strukturni i kohezijski fond,

14 Presudom prekršajnog suda u Bjelovaru, br. 13. Pp G-673/17-11, od 14. II. 2018., sud je zaključio da okrivljena gđa Bajević nije povrijedila zakon kada je štitila vlastiti interes i kada je odbila cijepiti svoje koze cjepivom protiv bolesti plavog jezika „Bluevac 4-G“ uvoznika Genera. S obzirom na to da navedeno cjepivo nije testirano za cijepljenje koza, niti je testirano na manjim skupinama prije masovne upotrebe, oslobođena je od optužbe i prekršajne odgovornosti što na svom gospodarstvu nije provela naređenu mjeru cijepljenja koza starijih od 3 mjeseca protiv bolesti plavog jezika u razdoblju od 4. V. 2017. do 10. XI. 2017.

15 U Uredbi br. 1151/2012, članak 29. uređuje kriterije koji se trebaju zadovoljiti pri dodjeli neobaveznog izraza o kvaliteti proizvoda, a članak 32. novi izraz naziva ,proizvod otočne poljoprivrede“. U smislu praćenja provedbe Uredbe, u članku 34.: „Države članice poduzimaju provjere koje se temelje na analizi rizika kako bi se osigurala sukladnost sa zahtjevima iz ove glave, te u slučaju prekršaja, primjenjuju odgovarajuće administrativne kazne“.

16 Na stranici 7. Izvješća, stoji: „Trenutačno ne postoji nijedan pravni instrument na razini EU-a ni na nacionalnoj razini izričito namijenjen zaštiti proizvoda koji potječu od otočnih proizvoda ili otočne poljoprivrede kao takve“. 
naime, ne uključuju se mali otoci povezani čvrstom vezom s kopnom. ${ }^{17}$ Izražava se uvjerenje o načinu definiranja pojma ,otok“ na način da ovisi o svrsi za koju je definicija potrebna. Komisija sugerira neka se odluči o definiciji „otok“ uz primjenu preciznog sadržaja koji će se oznakom prenositi, jer raznolikost otoka je velika.

Komisija u svom Izvješću dalje ističe neopravdanim utvrđivati posebna svojstva kao zajednička svim njihovim proizvodima namijenjenima za prehranu ljudi u Prilogu I. Mnogi otoci imaju jednu ili više zajedničkih robnih marki, sustavi kvalitete zaštićene oznake „ZOI“ i „ZOZP“ štite ih od zlouporabe i zavaravajućih ili nepravednih praksi, podliježu strožoj kontroli i/ili certificiranju za razliku od neobavezne oznake kvalitete. Također, mogla bi dodatno štetiti proizvođačima koji su već uključeni u sustave kvalitete time što ih se stavlja među konkurenciju. ${ }^{18}$ Komisija preporučuje označavanje i nadalje reguliranje na razini otočne članice EUa, prodaja otočnih proizvoda ionako se odvija na otoku i na kopnu vlastite države, a proizvodi se ne izvoze.

U procesu donošenja odluka najvažniju ulogu ima Vijeće sastavljeno od ministara država članica i stvara europsko pravo. Vijeće je raspravilo i donijelo Zaključak o Izvješću Komisije o opravdanosti uvođenja neobavezne oznake kvalitete ,proizvod otočne poljoprivrede“.${ }^{19}$ Ovim se dokumentom promiče kakvoća i raznolikost proizvoda, zatim se primjećuje da otoci, iako s poteškoćama, doprinose gospodarskom i socijalnom razvoju Unije. Vijeće, nadalje, zaključuje kako treba koristiti postojeće instrumente promicanja i zaštite poljoprivrednih proizvoda i svrsishodnim drži da svaka otočna članica izradi potprogram za otoke, te iskoristi sve postojeće alate za rješavanje problema otočnih poljoprivrednika. Zaključak je Vijeća da Komisija dalje razmatra vrijednosti specifične oznake kvalitete za otočne poljoprivredne proizvode kao nadopunu postojećim programima kvalitete EU-a, a uz dopunu: ,ali istovremeno uzimajući u obzir potrebu da se izbjegne moguća pomutnja u okviru trenutačnog zakonodavstva koja bi mogla naštetiti odgovarajućim sustavima oznaka zemljopisnog podrijetla“. Na kraju, Vijeće poziva Komisiju da pronalazi mjere za pomoć proizvođačima u priopćavanju značajki o dodanoj vrijednosti njihovih proizvoda, te da pruža informacije o instrumentima politike $\mathrm{i}$ mogućim prilagodbama politike.

17 Članak 52. Uredbe Vijeća (EZ) br. 1083/2006 o utvrđivanju općih odredaba o Europskom fondu za regionalni razvoj, Europskom socijalnom fondu i Kohezijskom fondu i stavljanju izvan snage Uredbe (EZ) br. 1260/1999 (SL L 210, 31. VII. 2006., str. 25).

18 Izvješće Komisije Europskom parlamentu i Vijeću o opravdanosti uvođenja neobavezne oznake kvalitete ,proizvod otočne poljoprivrede“, Bruxelles, 16. XII. 2013. COM(2013) 888 final.

19 Zaključci Vijeća EU, 10478/14 o Izvješću Komisije Europskom parlamentu i Vijeću o opravdanosti uvođenja neobavezne oznake kvalitete ,proizvod otočne poljoprivrede“, Bruxelles, 06. VI. 2014., s prilogom. 


\section{HRVATSKI OTOČNI PROIZVOD - NACIONALNI SUSTAV OZNAČIVANJA}

Hrvatski otočni proizvođači uključeni su od 2007. u nacionalni projekt označavanja proizvoda s oznakom „Hrvatski otočni proizvod“, temeljem Zakona o otocima i prije pristupanja Hrvatske u EU. ${ }^{20}$ Vizualna oznaka „hrvatski otočni proizvod" može se dodijeliti proizvodima koji su nastali kao rezultat tradicije, razvojnoistraživačkog rada, inovacije i invencije što utvrđuje ocjenjivačka komisija. Tijekom jedanaest godina i dodjeljivanjem ove nacionalne oznake postigao se odličan uspjeh u podupiranju raznolikosti otočnih proizvoda, proizvođači s otoka stekli su bolju tržišnu poziciju u odnosu na veće proizvođače u kopnenim županijama. Proizvodi s hrvatskih otoka s oznakom „Hrvatski otočni proizvod“ imaju danas poseban značaj, njihovi prehrambeni artikli odlikuju se karakteristikama koje proizlaze iz nutritivne vrijednosti sastojaka te specifičnosti u tradicionalnom načinu proizvodnje i otočnog podneblja. Udruga poslovni klaster „Hrvatski otočni proizvod“", registrirana u Šibensko-kninskoj županiji, uspješno djeluje u cilju jačanja konkurentnosti i izvrsnosti proizvoda i na unapređenju hrvatskih otoka putem umrežavanja relevantnih čimbenika. Lobiranjem na nacionalnoj i na razini Unije za državni projekt „Hrvatski otočni proizvod“ ostvaruje se suradnja na promicanju atraktivnosti naših otoka te i na uravnoteženom razvoju otočnih županija. ${ }^{21}$

U želji da se potakne otočnu proizvodnju i učini gospodarstvo konkurentnijim s otočnim prepoznatljivim proizvodima, oznaku „Hrvatski otočni proizvod“ mogu dobiti bez provođenja procedure i proizvodi koji su već zaštićeni oznakom ekološkog proizvoda, oznakom izvorno hrvatsko, oznakom hrvatska kvaliteta, oznakom tradicionalnog ugleda, oznakom izvornosti, oznakom zemljopisnog podrijetla, oznakom izvornosti za ostale proizvode, oznakom zemljopisnog podrijetla za ostale proizvode. ${ }^{22}$ Strane pravne i fizičke osobe također mogu zatražiti i dobiti zaštitne oznake zemljopisnog podrijetla ili oznake izvornosti za proizvode koje proizvode na našim otocima, i upisati se kao ovlašteni korisnici oznaka sukladno odredbama međunarodnih ugovora, odnosno konvencija.$^{23}$ Primjerice, hrvatski otoci udruženi u Otočnom saboru u nastojanju da pokušaju zajedničkim djelovanjem ubrzati razvitak hrvatskih otoka, pristupili su potpisom predstavnika Otočni sabor švedskoj mreži ESIN i od 2014. članovi su i te grupacije..$^{24}$ Budući da je ESIN-konvenciju potpisao predsjednik Otočnog sabora, otočne jedinice lokalne samouprave ovlaštene su

20 Na temelju čl. 16. Zakona o otocima (NN, br. 34/99, 32/2002 i 33/2006) donesen je Pravilnik o uvjetima, kriterijima i načinu označavanja proizvoda oznakom „Hrvatski otočni proizvod“ (NN, br. 47/2007).

21 Iz Statuta Udruge poslovni klaster „Hrvatski otočni proizvod“ koji je donesen temeljem čl. 13. Zakona o udrugama, 26. IX. 2015.

22 Prema članku 4. Pravilnika o uvjetima, kriterijima i načinu označavanja proizvoda oznakom „Hrvatski otočni proizvod“.

23 Sukladno članku 10. Zakona o oznakama zemljopisnog podrijetla i oznakama izvornosti proizvoda i usluga.

24 EGTS je ključan instrument Europske komisije za upravljanje teritorijalnom suradnjom i kohezijom. Na prijelazu u drugo financijsko razdoblje 2014. porastao je njihov broj. 
provoditi zadaće određene ovom konvencijom jače pravne snage od hrvatskih zakona. Hrvatski otoci u stranoj grupaciji zajedno s otocima Švedske, Danske, Finske, Francuske, Irske, Škotske, Estonije, Italije i Grčke mogu razmjenjivati razne otočne poljoprivredne proizvode sa zaštitnom oznakom. Međutim, svi otočni proizvođači složili bi se s argumentima protiv uvođenja EU-oznake „otočni poljoprivredni proizvod“ iz Izvješća Komisije. Proizvodi s tom oznakom ne bi upućivali na određeni otok i ne bi sadržavali logotip, a nije predviđena ni provjera za proizvođače u odnosu na sastav njihovih proizvoda (npr. preprodaja kozjeg sira umjesto uzgoja i proizvodnje od istog proizvođača).

\section{ZAKLJUČCI I IMPLIKACIJE}

Postoji više zaštitnih oznaka za otočne proizvode unutar hrvatskog i EUzakonodavstva ,koje su ostvarile svoj potencijal“. Umjesto njihovom zamjenom s jedinstvenom oznakom da ne dođe do nepoželjne zabune ili zablude proizvođača i potrošača, mišljenja smo kako im treba ostaviti prostor koji sada imaju za razvoj otočnog gospodarstva. Hrvatski otoci pripadaju području Unije od kada je 2013. Hrvatska postala punopravna EU-članica i u hrvatski otočni prostor, kao područje od posebnog državnog interesa i konkretnih razvojnih programa, ulažu se značajna investicijska sredstva za otočnu infrastrukturu. ${ }^{25}$ Uvođenjem neobavezne EUoznake „otočni poljoprivredi proizvod“ za sve europske otoke nestali bi mnogi proizvodi s popisa nacionalnog sustava označavanja „Hrvatski otočni proizvod“, koji se uspješno i u kontinuitetu razvija jedanaest godina na hrvatskom teritoriju. EU-instrumenti otočne politike, Rezolucija Parlamenta o posebnoj situaciji otoka koja predlaže otočnim članicama definiranje pojma „otok“ i posebnu situaciju na otocima, Izvješće Komisije o neslaganju s uvođenjem EU-oznake „otočni poljoprivredni proizvod“ iz Uredbe br. 1151/2012, te Zaključci Vijeća da se slaže s Izvješćem Komisije, mogu biti dobar temelj i hrvatskom potprogramu pomoći za otočne poljoprivrednike.

Svaka EU-otočna članica samostalno i jasno može definirati pojam „otok“, njihov broj i otočnu situaciju koju određuju specifične poteškoće. ${ }^{26}$ Hrvatska ima 1246 različitih otoka na moru koje znanost drži kopnenima, ${ }^{27}$ ima i naseljene otoke na jezeru i na rijeci koje još nije obuhvatila razvojnim programom. ${ }^{28}$ Rezolucija o

25 O tome u: Otočni logaritam - Aktualno stanje i suvremeni demografski procesi na jadranskim otocima, Lajić, R. Mišetić (2006.).

26 Naime, prema čl. 174. st. 2. UFEU/L-a, otočne teškoće nisu definirane: „... posebna se pozornost poklanja regijama koje su izložene ozbiljnim i trajnim prirodnim ili demografskim teškoćama, kao što su ... otoci, pogranične i planinske regije“.

27 „Naši otoci na Jadranu“, dr. sc. I. Rubić (1952.).

28 Izvješće Vlade RH o konzultacijama o zaštiti interesa RH u Jadranskom moru, usvojeno 2. studenoga 2017., navodi da Hrvatska kao obalna država ima 1142 otoka, otočića i hridi (str. 7.), iako je službeno od 2000. g. u uporabi broj od 1246 otoka (Kartografski odjel Hrvatskog hidrografskog instituta, dr. sc. Tea Duplančić Leder). Među otocima na moru nije Nin iako je stoljećima ranije imao status otoka. Pojam „otok“ odnosi se i na otok Visovac na jezeru NP Krka, i na otok Križnica na rijeci Dravi. 
posebnoj situaciji otoka značajno izmijenjena unutar mjesec dana, nije uobičajen pravni temelj pri donošenju nacionalnog zakona i odnosi se isključivo na najudaljenije otoke, one jasno različite od kopnenih regija. Hrvatski naseljeni otoci u novom su kontekstu od kada je njihova krovna udruga Otočni sabor pristupila švedskoj ESIN-mreži malih otoka. Otada postoji obveza razmatranja svih akata ESIN-mreže, konvencije, statuta, poslovnika o radu, strategije razvoja otoka, moguće i po pitanju zaštitnih oznaka za otočne proizvode. Naši otoci, iako financijski slabi i s malim nacionalnim tržištem, imat će perspektivu ako zadrže svoj gospodarski identitet.

Hrvatsko izaslanstvo u Odboru regija EU-a aktivno sudjeluje u definiranju područja politike na koja bi se Uredba o EGTS-u trebala primjenjivati. Iako formalne prijave za sudjelovanje u ESIN EGTS-u sa statusom „u pripremi“ nema, hrvatska udruga Otočni sabor objavila je svoje aktivno sudjelovanje u ovoj švedskoj mreži na svojim službenim stranicama. Otočni sabor potpisnik je ESIN-konvencije koja je dio prava Unije, a mjere otočne politike utvrdit će se na nacionalnoj i EU-razini. Primjer je projekt štednje vode radnog naslova „Water Saving Challenge Project“, bio je tema sastanka Komisije koja je organizirala skup 2. ožujka 2018., u Zagrebu, za ESIN-dužnosnike i hrvatske predstavnike otočne politike.

Grupacije ili mreže zakonski su oblik nastojanja da se zaobiđu pravila konkurencijskog prava kada se putem konvencije dogodi zajednički interes, npr. za povećanje uspješnosti poslovanja, a ne stvaraju negativni efekt na zajedničkom tržištu Unije ili njegovom većem dijelu. Pravila tržišnog natjecanja ne primjenjuju se jer je tržišno natjecanje eksplicitno uređeno posebnim propisima za pojedino tržište, tako npr. hrvatskim propisima o grupacijama PANNON. ${ }^{29}$ Hrvatski normativni okvir za sudjelovanje u razvoju EU-teritorijalne suradnje na području Republike Hrvatske točno određuje tko su akteri u njegovu provođenju, ali se u postupku usklađivanja hrvatskog prava teritorijalne suradnje još uvijek ne snalaze temeljem Zakona o provedbi Uredbi o EGTS-u (NN, br. 74/2014).

29 M. Rubić, Novi Informator, br. 6449, 19. XII. 2016.: „Europska grupacija teritorijalne suradnje“. Teritorijalna suradnja glavni je cilj EU-regionalne politike, djelotvornija uloga dodijeljena je EGTS-ima i Odboru regija koji ažurira listu i vodi registar EGTS-ova. Objašnjava četiri faze ili statusa pri osnivanju EGTS-a: „,ideja“ - potencijalni članovi poduzeli su istraživačke radnje ili preliminarne pregovore; ,u pripremi“" - priopćenje potencijalnih članova da se uspostavi EGTS i konvencija je u izradi; ,čeka odobrenje“ - potencijalni članovi obavijestili su državu članicu u kojoj je sjedište EGTS-a o namjeri za sudjelovanje; a „osnovan“ znači EGTS je stekao pravnu osobnost. 


\section{TRADEMARKS OF ISLAND PRODUCTS IN THE CONTEXT OF CROATIAN AND EU LEGISLATIONS}

Original products, characteristic of island areas, are a specific segment of the island economy, and the Croatian legislator enables promotion and market protection with labels of country of origin, appellations of origin, guarantees of traditional specialties, labels of 'Croatian eco-products' and 'Croatian Island Product'. The European Union refers to the provisions of article 174. The Lisbon Agreement emphasizes the need to develop political economic, social and territorial cohesion for island areas, as an opportunity for reducing developmental inequalities with mainland regions. To define the concept of ,island "and the problem area of islands, the amendment to the Resolution of Parliament on the specific situation of islands is significant which states that islands have not had financial assistance from 2014 to 2020 and that article 174 of the Lisbon Agreement is not clear.

Here, as a further EU instrument of island policy, emphasized is the Commission's Report on the justification of introducing non-compulsory labels of quality ,product of island agriculture "because it shows disagreement with this idea pursuant to Regulation (EU) on the system of quality for agricultural and food products no. 1151/2012. Also important are Council Conclusions because every island member can formulate its own program to resolve this problem of island producers. As EU acts are of a political nature, they are not binding, but it is necessary to follow them keeping in mind the interests of producers on Croatian islands which are included in the national system of quality „Croatian Island Product “. By introducing the mentioned non-compulsory EU appellations for agricultural produce from Croatian islands, producers would be at a disadvantage from the position of free market competition because they would be placed with their competitors. Finally, EU-actions are mentioned which are undertaken on islands in relation to transnational networks, and are already reflected on Croatian populated islands.

Key words: island product, appellations of quality, island agricultural produce, acts of EUpolicy, Croatian island product 